\title{
Universities Beyond 2020
}

\author{
Amr Salama
}

Universities play an important role as leaders in teaching and learning, in education, research and technology. Through their teaching activities, universities provide professional training for high-level jobs, as well as the education necessary for the development of the individual.

Universities are also important sources of many of the new ideas in science and technology that contribute to innovation.

Over the past few decades, tertiary education systems have experienced significant changes.

The great global upheavals shaping the world today are driving the fourth industrial revolution. Expansion of tertiary education, the growing demands of society for tertiary education, the increasing flow of students and the technological changes taking place due to the ICT revolution are today presenting universities with considerable challenges.

During the last two decades, the world has witnessed great changes that have been reflected in all sectors of society. These changes have also affected the concepts of power, work, progress and luxury, concepts which are linked to digital technology. The phenomena of information technology led to the emergence of a knowledge economy based on innovation and creativity if we consider that knowledge is the main source of wealth and the way to achieving a competitive advantage.

However, achieving this goal depends on the ability to invest in human resources (intellectual and knowledge capital), education and constant specialized training of the workforce, the effective use of information and communication technologies, using research and development as a motor of change and development for all sectors of society.

\footnotetext{
A. Salama (两)

Association of Arab Universities, Amman, Jordan

e-mail: aesalama@aaru.edu.jo 
At present, businesses and workers are facing challenges pushed by modern technology and digitalization. They have to be more innovative as they stand for progress and growth. Education and training are a precondition for innovation. The lack of relevant skills, rigid education systems and a reluctance to train and learn throughout one's professional life are obstacles to innovation in the world of work.

It is very important to empower individuals by giving them the relevant skills needed for the digital economy (critical and innovative thinking, communication skills, problem-solving skills, planning and organizational skills, etc.) to enable them to fully participate in the economic, social and cultural life of today and tomorrow.

The evolving nature of the digital economy requires individuals to rapidly adjust to the shifting demand for skills. Equipping individuals with strong foundation skills, high order thinking competencies as well as social and emotional skills would remove the greater levels of uncertainty for individuals. On top of this, digital literacy is essential in order to ensure inclusion in the digital economy and also society.

Today's reality has imposed new requirements for higher education to move to the knowledge economy, which is educational, human, technical, financial, social and cultural. This requires universities around the world to develop a strategy that takes into consideration the importance of the knowledge economy in the education system that it adopts.

This has prompted several international universities to develop their structures and systems to keep pace with the challenges of this era, strive to be smart and develop a digital global environment through steps such as training the staff and students, increasing ability to deal with the digital environment, developing the infrastructure for information technology, preparing research, expanding the scope of digital group management and working to provide the five elements that the smart university is based upon smart people, smart environment, smart management and governance, smart buildings and knowledge networks.

These universities that innovate will no doubt come out on the other side with stronger technology solutions and student support systems that will serve them for decades to come.

The study of the Humanities and Arts is as important as the study of natural and technical sciences. The Humanities encourage us to think creatively, to reason, ask the best questions, foster social justice and equality, teach us about various cultures, develop informed and critical citizens, enable us to understand the world around us; without the Humanities democracy would not flourish. Universities must continue to promote the Arts and Humanities within their disciplines. Establishing new branches of social sciences such as biological sociology, sociology of knowledge and sociology of technology makes the human being capable of adapting to all scientific research and the use of contemporary technology without bypassing systems of moral values, and without prejudicing the freedom of individuals or violating their dignity.

It is known that teaching, research, and community services are the three common functions of a university. Encouraging students to reflect on their moral beliefs and those of other people, fostering the values of responsible citizenship, peace, tolerance, harmony, pluralism, and co-existence. These aspects of the common good are not well represented at universities in its present form. 
To have education for a better society and the common good, I think universities should shift their focus to real-world problems and social transformation. That does not mean displacing job-specific education and research.

We should not lose sight of the Sustainable Development Goals. Making them a reality will require the participation of everyone, including governments, the private sector, civil society organizations, as well as the general population from around the world.

Some trends that will shape the future of higher education: Blended Learning will increase dramatically, and online education will be a strategic priority at every institution; lifelong learning will become more important than ever; students would undoubtedly be concerned that universities should continue their reforms to meet their needs and ensure good quality delivery; universities will also have to build further links and nurture long-term relationships with industry; universities will need to adjust their courses, curricula, and degree programmes to meet learners' needs, as well as the demands of new industries and an evolving workforce and the growing of the use of AI.

Since its foundation in 1950 under the aegis of UNESCO, the International Association of Universities (IAU) followed and is still following its mission to help its member institutions and organizations to achieve their common goals through international cooperation worldwide while keeping their cultural differences.

Among others, IAU contributes to the development of the long-term vision of the university's role and social responsibility; encouraging quality and design and implementing programmes for its Members, in partnership with other organizations working in the same field.

IAU fulfils its mission and contributes to global dialogue through conferences, webinars, workshops, experience-sharing, collaboration, networking, specialized portals, surveys, and analyses, as well as through its various reference and scholarly publications.

To the 70th Anniversary of IAU, I would like to say that we, at the Association of Arab Universities, are very pleased to work and cooperate with IAU to raise the international profile of the universities and achieve the SDGs for a better world.

Amr Salama is Secretary General of the Association of Arab Universities and Professor of Structural Engineering and former president of Helwan University, Egypt. He was the Counselor of The American University in Cairo and is the Former Minister of Higher Education, Scientific Research and Technology of Egypt. Dr. Amr Salama is also the Chairman of the Management Engineering Society, as well as the Chairman of the Council of Housing and Building of Academy of Scientific Research and Technology. 
Open Access This chapter is licensed under the terms of the Creative Commons Attribution 4.0 International License (http://creativecommons.org/licenses/by/4.0/), which permits use, sharing, adaptation, distribution and reproduction in any medium or format, as long as you give appropriate credit to the original author(s) and the source, provide a link to the Creative Commons license and indicate if changes were made.

The images or other third party material in this chapter are included in the chapter's Creative Commons license, unless indicated otherwise in a credit line to the material. If material is not included in the chapter's Creative Commons license and your intended use is not permitted by statutory regulation or exceeds the permitted use, you will need to obtain permission directly from the copyright holder. 